\title{
Fiscal Sociology and Veblen's Critique of Capitalism: Insights for Social Economics and the 2008 Crisis
}

Ceyhun GÜRKAN (https://orcid.org/0000-0002-8048-7175), Department of Public Finance, Ankara University, Turkey; e-mail: cgurkan@politics.ankara.edu.tr

\section{Mali Sosyoloji ve Veblen'in Kapitalizm Eleştirisi: Sosyal İktisat ve 2008 Krizi için Düşünceler}

\begin{abstract}
The purpose of this paper is to review fiscal sociology and Veblen's critique of capitalism with an eye to developing new insights for social economics and the 2008 crisis. The paper adopts an interdisciplinary approach that blends history, political economy, politics, sociology, social philosophy, and ethics. The article demonstrates how old and new strands of fiscal sociology and Veblen's economic sociology can be employed to develop a comprehensive understanding of history, present conditions and future of neoliberalism as well as its current crisis. The paper concludes that fiscal sociology and Veblen's sociological and critical institutional economics have the great potential to develop new insights into critical social economics and the fiscal crisis of the state.

Keywords

Fiscal Sociology, Veblen, 2008 Crisis, Capitalism, Neoliberalism.

JEL Classification Codes : A14, B15, H00, Z1.

$\ddot{\mathbf{O} z}$

Bu yazı sosyal iktisada ve 2008 krizine dair yeni düşünceler geliştirmek üzere mali sosyolojiyi ve Veblen'in kapitalizm eleştirisini gözden geçirmektedir. Yazı tarihi, politik iktisadı, siyaset bilimini, toplumsal felsefeyi ve etiği harmanlayan disiplinlerarası bir yaklaşım benimsemektedir. Yazı mali sosyolojinin eski ve yeni tarzları ile Veblen'in iktisat sosyolojisinin neoliberalizmin tarihini, bugünkü koşullarını ve geleceğini ve ayrıca krizini anlamada nasıl kullanılabileceğinin yolunu göstermektedir. Çalışma mali sosyoloji ve Veblen'in sosyolojik ve eleştirel kurumsal iktisadının eleştirel sosyal iktisat alanında yeni düşünceler geliştirmek ve devletin mali krizi olgusunu incelemede güçlü bir potansiyel sunduğu sonucuna ulaşmaktadır.
\end{abstract}

Anahtar Sözcükler $\quad$ : Mali Sosyoloji, Veblen, 2008 Krizi, Kapitalizm, Neoliberalizm. 


\section{Introduction}

It has been more than a decade now since the 2008 global crisis, but it still creates ongoing formative and forceful negative influences on the societies and economies of developed and developing countries. As such, scholars and researchers from a wide range of academic disciplines have become all the more focused on the crisis to evaluate its multiple causes and effects in connection with their specific academic engagement. Scholars and researchers in a range of disciplines, including history, sociology, politics, public finance, and economics frequently meet in the academic and social venues to discuss the crisis and set out expectations about what is in store in the coming years for economies, social life, and politics at the national and global scale. It is now a common idea that a multidisciplinary social-economic approach is a key to advance realist accounts of the crisis and deliver convincing explanations of the causes and mechanisms of the crisis as well as offer practical solutions to overcome its wide-ranging damaging effects.

The 2008 global economic and financial crash is recognized as 'great regression' (Geiselberger, 2017) not only because of its multi-destructive effects on economic growth, national welfare systems, and economic equalities but also because of its extensive detrimental effects on social, cultural and political systems and structures. The demise of democratic culture, rise of counter-attitudes against modernity, upsurge of right-wing populism supporting extreme nationalism, loss of classical liberal values and public interest, escalation of violence and racism, increase of socio-political inequalities between ethnic groups and sexes are among non-economic vicious phenomena and consequences seen as directly linked up with the global crisis of 2008. It was an economic (in the sense of real economy), financial and fiscal crisis but given its roots in the comprehensive neoliberal structuring of societies and states as of 1980 and its wide-ranging non-economic consequences the crisis has also paved the way for the tendencies of political and social crisis. As such, in that setting, it is now shared on all sides that a sociological inquiry grounded in institutional political economy is the key to present a critical revision of both the dominant theories of public finance and economics as well as the actual course of the crisis.

Sociology is the immediate neighboring discipline of political economy and social economics, in that sociology theoretically and empirically deals with the organization, structure, and evolution of the society. Sociology is engaged with a series of fundamental questions such as: How does the present society change? Where is the direction of social change? What are the immediate and indirect factors of social change? In retrospect and with hindsight, we see now that the 2008 crisis played a decisive role as a turning point in the social evolution of the capitalist societies and it induced unprecedented and irrevocable socio-economic and political developments. Sociology with its sub-branches (notably cultural sociology, political sociology, economic sociology, and fiscal sociology) helps us develop a holistic approach to achieve a comprehensive and adequate understanding of the crisis as both a unique event and a structural process. 
This article takes its departure from this now-common idea of the urgent need to develop multidisciplinary critical accounts and offers a broad outline, research agenda and conceptual tools to study the 2008 global crisis from two sociological frameworks: fiscal sociology and economic sociology of Thorstein Veblen. In the context of fiscal sociology, two Austrian economists and sociologists -Rudolf Goldscheid and Joseph A. Schumpeterwill be reviewed as the founding figures. The fiscal sociological framework is the first step in the present paper to reveal the exact process and causes of the 2008 crisis which affected directly public finances in Europe. It is, ideologically, called 'sovereign debt crisis' to make the crisis seen as an outcome of the wrong fiscal policies of the states. 'Fiscal sociology' or 'financial sociology' (Finanzsoziologie), a term derived by Goldscheid, is the first sociological framework to explain the historical and political relationship between the state, economy and fiscal crisis to deliver convincing insights to understand economic and fiscal policies as well as social changes. After Goldscheid, the focus of the paper will be brought on Schumpeter and then on the contemporary approaches of James O'Connor and Wolfgang Streeck to provide a restructured critical sociological framework of public finance in the face of actual developments in the neoliberal capitalist economy and society.

In turn, Veblen's sociological and institutional political economy of capitalism and business will be reviewed as the second sociological framework to build up a critical approach to business enterprise and financialization. Economic sociology is a distinct research field and has its research agenda with different strands around the themes of social aspects and non-economic consequences of economic life, embedded and disembedded structures and processes of the capitalist economy, the interaction of economic and noneconomic rationalities (Smelser \& Swedberg, 2005; Swedberg, 2003). In the scope of the present study, Veblen is regarded as one of the primary economic sociologists to develop a sociological understanding of, conceptual tools for and theoretical view to the present and prospective conditions of neoliberalism as a business order. The 2008 global financial crisis is the immediate result of the expansion of finance capital and financial logic. The works of Veblen on business and its financial relationship to the real economy of the industry will be presented to demonstrate how the crisis can be studied from the institutional and cultural political economy perspective. In doing so, Veblen will be reviewed around the present neoliberal realities.

Overall, the 2008 crisis has still large, profound and exhaustive effects on the society at large under the sway of austerity policies. In the wake of the 2008 crisis, particularly the harmful and continuing impact of financialization on the state, society, and individuals has become the main subject in various academic disciplines and critical studies. The sociological critique of financialization gains ground, too. Sociology joins debates by pursuing interdisciplinary economic studies such as (new) economic sociology, (new) fiscal sociology, financial sociology, and heterodox economics. In the face of the multidimensional effects of financial capitalism on the societal systems at macro and micro scales, this study aims to contribute to the growing sociological critique of neoliberal financial capitalism by drawing on Goldscheid, Schumpeter, O'Connor, Streeck, and Veblen. 


\section{Fiscal Sociology and the Fiscal Crisis of the State}

Two Austrian economists and sociologists Goldscheid and Schumpeter are recognized as the founders of fiscal sociology. They offered fiscal sociology as a distinct research field in the social sciences. However, according to the entry of Finanzsoziologie in a German dictionary of economic concepts, fiscal sociology had already been employed by two political scientists in the 19th century- Johann Karl Rodbertus and Albert Schäffle (Koch, 1981: 97-98). Thus, the historical evidence shows that the term 'fiscal sociology' (Finanzsoziologie) emerged in the German-speaking lands. Finanzsoziologie is translated into English either as 'fiscal sociology' or as 'financial sociology' less commonly. The latter today is seen related to a field of study focused on the sociological interpretation of financial institutions in the private sector whereas fiscal sociology is directly and solely related to state financing. A small part entitled 'A Sociological Approach to Problems of Public Finance' from Goldscheid's book dated 1917/1925, Staat, öffentlicher Haushalt und Gesellschaft: Wesen und Aufgaben der Finanzwissenschaften vom Standpunkte der Soziologie, was translated into English in 1958 where the term 'financial sociology' was used. In the English translation of Schumpeter's article entitled 'Die Krise des Steuerstaates' (1918) ('The Crisis of the Tax State', 1954) the term 'fiscal sociology' was preferred. Since Schumpeter's translation, fiscal sociology is in full use in the works of sociological studies of public finance. On a closer examination, however, the difference between the two translations is not only conceptual but seems to have been stemmed from the distinct problematizations of the system of public finance by Goldscheid and Schumpeter. As will be made explicit, Goldscheid made a critical sociological analysis of the close relationship between the imperialistic financial capital with the state finance, whereas Schumpeter wrote a history of taxation with a debate of tax policies to overcome the fiscal crisis of the Austrian state after the World War I and set forth a pessimistic prediction of the future of the tax state. These different problematizations of the capitalist tax state might have inclined translators to the diverse translations of Finanzsoziologie.

By comparison, Goldscheid's approach, which explores the historical relationship between the financial and the fiscal, is critical of the free-market capitalist economy and his analysis bears more immediate and direct arguments and implications for the near past and current state of capitalist economic/financial affairs. He based his analysis on a critical appraisal of taxation and the state debt vis-à-vis the political actualities and urgencies of his day. Schumpeter's study, on the other side, focused on taxation is more of historical, methodological and speculative as he pessimistically predicts the coming end of capitalism and the tax state. Goldscheid's analysis of public finance can be summed up around his main contributions to the social theory of public finance as regards i) methodology, (ii) political analysis of the state, public finance, and financial capital, and (iii) policy recommendations relying on the state capitalism to overcome the fiscal crisis of the state. His second and third contributions are highly debatable; however, the first is less so because the method he offers is sociological in the broadest sense and has certain aspects of political economy which is shared by the entire fiscal sociology scholarship. Goldscheid sees sociology indispensable for the science of public finance because, in his words, "[o]nly sociology can show how social conditions determine public needs and the manner of their satisfaction by more direct 
and indirect means, and how ultimately the pattern and evolution of society determine the shaping of the interrelations between expenditure and public revenue" (Goldscheid, 1958: 202). With this insight about the sociological nature of public finance, Goldscheid ushered the traditional topics of public finance (revenue, debt, and expenditure) into a politicalsociological inquiry of the evolutionary change and organizational structure of society. Besides, he constitutes another symbiotic relation by arguing that the structural change of society is also determined by public finance: "The pattern of public finance has at all times had a decisive influence on national and social evolution" (1958: 202).

In line with these sentiments, Goldscheid calls his method Finanzsoziologie and takes a further step towards coupling it with critical political economy, arguing that " $[\mathrm{t}] \mathrm{ax}$ struggles were the oldest form of class struggle, and fiscal matters were an important contributory cause even in the mightiest spiritual movements of mankind" (1958: 202). In the same manner, he notes: "Fiscal exploitation is the oldest form of exploitation besides outright slavery" (1958: 204). Goldscheid's materialist and critical sociological evaluations offer much to express the current conditions of the tax states in crisis especially regarding the question of the structure and direction of the change of (neo)liberal society. For Goldscheid, only a critical sociological analysis of capitalism and public finance in which political economy is the main supplement is capable of producing answers to the question of social structure and change. For an objective and realist science of public finance, Goldscheid argues, fiscal sociology is the most important tool to illustrate the macrostructure of the fiscal economy as well as "the destiny of nations and individuals alike" (1958: 206207). His theoretical and ideological position is diametrically opposed to the neoclassical (marginalist) theory of public finance which turns the concrete sociological and political dimensions of the fiscal system into a 'mental science' (Schabas, 2005) replacing the materialist and structural theory of public finance handed down from the Scottish political economy. Goldscheid's view and arguments bear raising a critique of the neoclassical theory of public finance, thereby developing a critical fiscal theory and policies with a strong orientation towards the state intervention and the public spirit.

Goldscheid's fiscal sociological analysis is significantly and directly pertinent to analyze the 2008 crisis and the post-2008 crisis period owing to his critical understanding of the controlling power of creditors or financial capitalists over the national public finance systems. Goldscheid maintains that the course of capitalist development from its early time down to his day paved the way for a situation he called "expropriation of the State" (Goldscheid, 1958: 203) by capitalist classes, notably by creditors. The state has become extremely a "poor State" (1958: 204) under the auspices of advanced imperialistic financial capitalists and "exploitation by the State [that is, 'fiscal exploitation'] ended up in exploitation of the tax State" (1958: 205) by capitalists. This is the historical fact capitalist classes have made for: "The rising bourgeois classes wanted a poor State, a State depending for its revenue on their good graces, because these classes knew their own power to depend upon what the State did or did not have money for" (1958: 205). The conditions of the poor state and exploitation of the state helped capitalist classes form "the State within the State" (1958: 210). Goldscheid, therefore, sees history as a battle between the state and capitalism although he refers to class relations. However, his reflections on class relations are rather 
economically reductionist and instrumentalist, since he sees the state as "the instrument of the ruling classes by the fiscal organization which they imposed upon it" (1958: 211). Accordingly, he does not approach the state as the outcome of the complex social relations and struggles between the classes in the capitalist system.

Politically being a firm statist, Goldscheid sees the state as the source of morality, justice and wealth. The state in the Hegelian sense is something that is and should be, separate from society and economy, and as such should be understood from its inherent characteristic. For Goldscheid, "[o]nly a rich State can be a just State" (1958: 210). For a rich state, the state's productive force and economy should be reclaimed by the public authorities against capitalists. As a result of this, "human resources" or "high-grade organic capital" (that is 'working class' or 'proletariat'), which are regularly open to the devastation of the competitive capitalist economy, can be restored and controlled by the state economy and politics. Therefore, the state can protect and enhance the productive capacity of human capital which increases the economic power of the state. The state should also take control of the public property to the full to enhance investments and generate a "socially productive economy" (1958: 212) under which the capitalist economy can work stable and safe. Goldscheid's plan is the model of 'state capitalism' which rests on a "public property order" (1958: 213). For Goldscheid, "State capitalism and human resources are the two basic pillars of an orderly economy" (1958: 212). In Goldscheid's design of the public finance system, 'orderly economy' as well as the material interest and needs of society can be achieved only by the state capitalism whose material science is sociological public finance. Fiscal sociology, for Goldscheid, is the science of the state capitalism that seeks to reformulate public finance as "a theory of public property" (1958: 213). For Goldscheid, the tax state as a specific form the capitalist state is open to exploitation by capitalist classes and he wants to replace this form of the state with an industrial state that has the majority of capital goods and controlling power over the economy.

In line with these arguments, Goldscheid aims at building up a prosperous, vibrant and democratic society, but, interestingly enough, his vision and ideas were later used and supported by the Nazi ideology (Lemke, 2011: 107-111). His strong emphasis on the social order regulated and guarded by the state order, his conception of the state as an entrepreneurial force and design of the human being as an economic subject, i.e, human capital, and his methodological and political ignorance of the importance and power of the working class in capitalist society allows Goldscheid to envisage a one-dimensional democratic system whose sole criterion is the elimination of the threat of "a State within the State" (Goldscheid, 1958: 211) - a conception which refers to the state as the instrument of capitalist classes, particularly creditors, but also implicitly of the proletariat. Therefore, his notion of the 'orderly economy', which rests on an idea that the political power of the proletariat is as dangerous as capitalist classes for the state and the 'orderly economy', brings his analysis open to being filled up by anti-democratic ideologies and policies as the history evinces. This means that Goldscheid's objections to the free-market capitalist economy and his sociological public finance might turn into repressive and authoritarian state capitalism and police science of communal economy respectively when it meets with anti-democratic ideologies and regimes. Democratic views and values are critically important for 
sociological public finance and Goldscheid's methodological suggestion of fiscal sociology should be encouraged and furthered by a comprehensive critique of his political and normative system of state capitalism. Towards that aim, Schumpeter's liberal attempt emerged as the first step in 1918.

Schumpeter penned 'The Crisis of the Tax State' (1991 [1918]) in the post-war conditions of Austria as a critical reply to Goldscheid's political attitude and policy solutions, but he agrees to Goldscheid's policy offer of the once-and-for-all capital levy for the wrecked Austrian economy and financial system after the World War I. Without any reservation, Schumpeter adopts Goldscheid's method of fiscal sociology. Methodologically, Goldscheid and Schumpeter are on the same line. Schumpeter, in the same manner with Goldscheid, argues that sociology is the most helpful and powerful tool to comprehend the complex social conditions of fiscal crisis and where the evolutionary drift of the liberal society and capitalist economy will possibly head to in the future. Schumpeter sees fiscal sociology as "a special field" (Schumpeter, 1991: 101) to achieve a comprehensive understanding of the complicated and general history and structure of society, and nature of the tax state, its limits, dynamics of its fiscal crisis and policy solutions to surmount the crisis. Schumpeter sets forth the term 'tax state' as an analytical and foundational concept through which the liberal society and capitalist economy, and their forms and faith can be better grasped. Also, for Schumpeter, fiscal sociology is a distinct and special field that has the potential to generate the practical proposals to overcome the crisis of the tax state and find out the causes for the failure of the capitalist state and prospective conditions of the next stage, i.e. socialism, after capitalism. In this sense, different from that of Goldscheid, in Schumpeter's design of fiscal sociology, the causes and conditions of the post-capitalist society as a result of the failure and disintegration of the capitalist system are the issues to be explored. For Schumpeter, as also proposed in his Capitalism, Socialism, and Democracy (1950 [1942]), the tax state and its social order, that is capitalist state and liberal society, can collapse, not because of the failure of the system and concomitantly the oppositions of revolutionary forces to it, but because of the success of the capitalist system which paves foundation stones for rationalization and irrationalities against capitalist logic and system, e.g. bureaucratization, monopolization, socialistic attitudes and the loss of liberal individualistic values, norms and actions like entrepreneurialism.

After Goldscheid and Schumpeter, fiscal sociology has taken several directions through various contributions made by Marxist accounts (O'Connor, 1973), public choice theory (Wagner, 2007), social-democratic approaches (Musgrave, 1992), neoSchumpeterian studies (Backhaus, 2004; Ebner, 2005), gender studies (McCaffery, 2009) and political-sociological studies in taxation (Campbell, 1993). These studies have made significant contributions to fiscal sociology. Their interest in fiscal sociology revolves around specific issues. These are the critique of neoclassical economic theory of public finance, the critical analysis of the disciplinary structure of mainstream public finance theories, new ways for developing sociological and political conceptions of public finance, social and political history of public finance, history of fiscal thoughts, the revision of Schumpeter's theory of 'the crisis of the tax state' in regard to the present conditions of fiscal systems and crises, and methodological debates on public finance. 
Among the recent contributions mentioned above, the two are notable. The first is the wave of 'new fiscal sociology', and the other is Wolfgang Streeck's fiscal sociology grounded in the critical institutional political economy. 'New fiscal sociology' introduced by the book, The New Fiscal Sociology: Taxation in Comparative and Historical Perspective (2009) calls for opening up new entry points of reflections on public finance and themes in fiscal sociology scholarship. The new fiscal sociology aims to bring fresh ideas into the sociology of public finance with a series of new topics such as gender, ethnic and race inequalities, ethics, psychological and subjective determinations of public finance, democracy and neoliberalism. This new trend has strong cultural and sociological orientations towards public finance issues, in particular, taxation. As such, this new wave in fiscal sociology aspires to transcend the classical approaches traceable back to Goldscheid and Schumpeter which are focused on large-scale socio-fiscal phenomena to the exclusion of micro domains and political-cultural relations in society such as gender issues, democracy, micro-power relations, and subjectivity.

Not directly and by name involved in the new fiscal sociology initiative, Streeck, however, has made one of the most significant contributions to revive the interest in fiscal sociology in his two recent books - Buying Time: The Delayed Crisis of Democratic Capitalism (2014) and How will Capitalism End? Essays on a Failing System (2016). Under the effects of the 2008 financial crisis, fiscal sociology has been brought back into prominence in Streeck's works in question. Streeck has given fiscal sociology a new direction by linking it up with the debate of fiscal crisis triggered off by neoliberal financedominated capitalism. In doing so, the classical problems of fiscal sociology shaped by Goldscheid, Schumpeter, and O'Connor, i.e., fiscal and financial crises, the role of the state and its class-based structure, and their combined effects on the possibility of the end of capitalism are reframed by Streeck. Streeck's empirical, institutionalist, historical, sociological and political-economy analysis can be seen as a follow-up of O'Connor's analysis of the fiscal crisis of the state by adding it the financial and global dimension of neoliberal capitalism which was ignored by O'Connor due to the structure of capitalism in the early 1970s. The Marxist fiscal sociology developed by O'Connor can be seen outdated to explain the contemporary fiscal crisis of the state after 2008 for some reasons (i.e. changing conditions of fiscal discipline, international politics, class relations and new social movements and so on). One important reason for this is that in O'Connor's theoretical framework, as noted, global financial capital does not have a role in causing the fiscal crisis of the state, but this was due to the historical conditions of the Keynesian welfare state and regime under which the accumulation of financial capital was subjected to the strict state regulations. Thus, O'Connor's theoretical and analytical framework can be developed further from a critical fiscal sociology perspective to explain the 2008 sovereign debt crisis by re-examining the new ways and means of the classical functions of the capitalist state, i.e., legitimate and accumulation functions shaped by the financialization process of the state and economy. Streeck's fiscal sociology grounded in the institutional political economy has this aim.

Towards that aim, Streeck reconsiders Goldscheid's analysis of the debt state (or poor and injustice state) as a result of the dominance of finance capital on public finances, 
Schumpeter's discussion of the crisis of the tax state and the likely end of capitalism in the long run, and O'Connor's Marxist analysis of fiscal crisis by giving it an institutional political economy direction and character to analyze the socio-political, cultural and economic conditions of the neoliberal finance-led capitalism, its detrimental effects on democratic system and culture, and the crisis and likely end of democratic capitalism. Streeck's fiscal sociological analysis is particularly critical because it is, like that of O'Connor, sharply opposed to the formulations of fiscal sociology carried out by public choice scholarship following the neoliberal agenda. Public choice theory-grounded fiscal sociology explains the reason of the capitalist economic system and its democratic system as a result of the expansion of the political market over the market economy (or the market proper). This culminates in the increase of the public property at the expense of private property, but the public property will be devastated in the end by leaving society with a massive volume of public debt and a ruined economy. Public choice theory concludes that parliamentary democracy is open to being corrupted by the conflicting interests of individuals in the political market and against this fact, political regulations should be established as constitutional rules under (neo)liberalism. Politics and democracy in public choice theory are conceived as the catalytic interactions of rational and self-interested individuals, particularly between bureaucrats, politicians, and voters, thereby ignoring the real ontological foundations of politics and democracy based on institutions (or 'habits of thought', as Veblen calls, which are not necessarily rational), history, radically contingent course of events, class and non-class relations as well as structurally integrated economic and non-economic systems. In this sense, Streeck's analysis is a considerable contribution to set fiscal sociology back on the institutionalist track to deliver democratic and realist accounts of fiscal sociology against neoliberal and anti-democratic finance-led capitalism.

Streeck's reframing fiscal sociology with institutional political economy is helpful to understand the 2008 crisis within the historical scope of the capitalist economy, how the crisis has morphed into the crisis of democracy and what comes next. For Streeck, in line with Schumpeter's opinion, capitalism has little chance to overcome the crisis and make another successful start. This is so, because three main reasons behind the crisis lead Streeck to anticipate the coming end of democratic capitalism: "decades of declining growth, rising inequality and increasing indebtedness - as well as of the successive agonies of inflation, public debt and financial implosion since the 1970s" (Streeck, 2016: 57). These have created five "systemic disorders" which are likely to condition the future of democratic capitalism in a way to put an end to it: "stagnation", "oligarchic redistribution", "the plundering of the public domain", "corruption" and "global anarchy" (2016: 28-34). These are powerfully transformative and challenging conditions and outcomes for the social order of capitalism to persist into the future. Stable capitalism needs a definite social order based on a democratic political system and a form of state, i.e. the tax state. However, the democratic institutions of capitalism have already mainly been devastated by the neoliberal finance-led regime and its accumulation and legitimation functions based on the expansion of private credit system instead of the development of social rights and justice protected by political and fiscal authorities. 
Streeck's analysis of contemporary capitalism and its faith in the future rests on the conception of the changing form of the capitalist state from the second half of the 20th century until 2008 and down to the present time. These diverse forms represent the evolving of the Keynesian democratic tax state (1945-1973) into the debt state (1980-1990) and finally into the consolidation state, the first period being between 1990 and 2008 under the fiscal discipline regime and the second being the post-2008 period shaped by austerity policies. These forms or types of the capitalist state refer to the changing structure of the public finance system and its relation to the capitalist economy and social order. Streeck's analysis $(2014 ; 2016 ; 2017)$ conceives the public finance system on the basis of the changing forms and structures of the capitalist state and this is the most distinguishing aspect of his fiscal sociology alongside his sociological divide of the society in the debt state into 'Staatsvolk' ('the general citizenry') and 'Marktvolk' ('the people of the market') (2014: 8081), which is a Goldscheid-style conception of fiscal sociology. It is noteworthy to underscore that each of these forms of the state has emerged out from the previous one but not eliminating the earlier, each representing the dominant form which means that the roots of the consolidation state can be traced back to an earlier period of the tax state. As such, the consolidation state is still a tax state and debt state, but the state's relation to politics, society, culture, and economy is carved out in a way to fit the structure of the consolidation state.

Very briefly, the tax state is a form of the state whose revenue is primarily composed of tax revenues and bears relatively more democratic character. The state debt developed at the end of the 1970s, reacting against the economic and political conditions of the tax state and arranging specific fiscal and monetary policies to overcome the crisis which opened the state finance to the global finance capital, thereby debt become the essential revenue of the state finance. The consolidation state has emerged out of the reaction against the crisis of the debt state in the early 1990s and represents the certain policies of fiscal discipline to sustain the articulation of the debt state with the global financial order (more on this see Streeck, 2017). The kernel of the consolidation state is to keep safe the global financial order and govern or, better still, construct the society in accordance with the needs of the neoliberal regime of global financialization. The first period of the consolidation state resulted in the global financial crisis and sovereign debt crisis in Europe; and after the crisis down to the present day its second period has been largely concerned with the socialization of the debt through the austerity policies by devastating the remnants of democratic institutions of the capitalist economy handed down from the Keynesian tax state.

Given our space constraint, Streeck's analysis and findings cannot be summarized entirely here but what is notable for emphasizing is that his studies into the near past, present condition and future of capitalism is essential to rethink and reframe public finance with historical sociology and institutional political economy. His approach is also grounded in political sociology in the normative sense that is concerned with the aim of changing the course of neoliberal capitalism towards a democratic order at the national and global scale. Streeck's call for sociology and institutional political economy for a critique of neoliberal capitalism rests on the defense of the material welfare of the society (Staatsvolk) against the global moneyed interest groups (Marktvolk) accumulating immaterial wealth in the form of financial capital. For this, industrial employments and Staatsvolk's material and peaceful 
culture, the material welfare of the society, around its anthropological, historical, political, cultural and economic dimensions, should be put as a first priority in the positive and normative sense in the research agenda of fiscal sociology scholarship against the warfare and predatory regime of global anti-democratic vested-interest classes, who have "a legitimate right to get something for nothing” (Veblen, 1964: 169). This framework exceeds the established field of fiscal sociology and takes us into a broader domain of economic sociology. Thorstein Veblen who wrote his final texts just before the Great Depression of 1929 should be recalled at this stage.

\section{Neoliberal Capitalism as New Business Order in Light of Veblen's Institutional Political Economy}

Veblen's sociological, evolutionary and institutional political economy presents a wide-scope framework through which the 2008 crisis can be grasped with its multiple causes and effects. Veblen's system of thought rests on a range of critical factors of capitalism. These factors in the following identify the principal components of the capitalist economy and society. These are business and business enterprise, predatory instincts and habituations in the form of institutions against the peaceful counterparts (the instinct of workmanship and parental instincts), pecuniary/business employments against industrial employments, business culture of leisure, its conservative 'leisure class' (Veblen, 1973) structure as a ceremonial institution, political institution and organization in the form of (imperialistic) nation-state and its unproductive governmental and militaristic employments, the price system and its main strategies, i.e. taxation, credit system and 'sabotage'(Veblen, 1994) of industrial system for enduring capitalization and high profits, business order's legal and philosophical system, i.e. 18th-century doctrine of natural law and right, by extension its (neo)classical theory of economics.

In Veblen's system, all these are tightly interwoven in a way to constitute an entangled network of business and industrial order. This means that each does not exist in its own right; as such one is inseparable from the rest, dependent on others and achieves its position, reality, actuality and activity in a sequence relation with others. This also means that the perspectives, theories, and discourses of this entangled business and industrial order have specific performative character, not merely being a matter of neutral epistemological element. Accordingly, knowledge -be it theoretical and philosophical or experience-based knowledge in daily life and belief systems, etc.- shapes reality and vice versa. Knowledge, in the final analysis, being 'habits of thought', and practice are not separable quite the reverse, they are positioned in a symbiotic relation in Veblen's system of thought.

That said, let's begin the epistemological module of Veblen's system of thought, that is, the role of the philosophy and economic theory in the constitution of reality. This is particularly relevant for the analysis of the current crisis of neoliberalism because, as frequently emphasized by the critics both from within and outside the mainstream economics, economic theories had defined roles in the occurrence of the 2008 crisis. For critics from inside, mainstream theories were lack of capability in predicting the coming turmoil and improving certain regulations to overcome the crisis. For critics from outside, 
the problem with these theories is much more deep-seated because they cannot explain the structure of the capitalist economic system, so they inherently are incapable of predicting crises and delivering policies for the stable order and the material welfare of the society. In line with the second lineage, from the perspective of Veblen, the most recent mainstream theories are still in the tradition of 18th-century legal-philosophical thought and (neo)classical economics. This being so, they are not evolutionary science in toto. Thus neoliberal economics, being a non-evolutionary science, is the employment of business the highest attention of which is to secure the stability of the price system, mostly for the safety of business/financial capital.

Veblen is known to coin the term 'neoclassical economics' which emphasizes the continuing relationship between classical political economy of the 18th century and neoclassical economics. 18th-century philosophy of natural law and right plus their nonevolutionary character are the bases of both classical and neoclassical economics. Neoliberal economics and its performative role in the 2008 crisis can be best understood by its relation to these past generations of (neo)classical lineages of economics and the foundational philosophy of natural liberty with the economic assumptions derived from it. First, from Veblen's point of view, liberal orthodox economic theory extending from classical economy to neoliberal economics is not an evolutionary science due to its uncompromising consequentialist, teleological/deductive, taxonomic preconceptions and abstractly constituted humanistic proclamations either in the form of rational hedonistic economic man (homo economicus) or the subject of right (homo juridicus) in accordance with the natural philosophy of law and order (Veblen, 1998; 2011). Rather than focusing on the economic process as a "life process" unfolding in "cumulative causation" in the unremitting sequence of the radically contingent 'events' from an evolutionary point of view, mainstream economics produces only "logically consistent propositions concerning the normal relations of things" (1998: 408). Orthodox economics, certainly, deals with real things and order but is not engaged with the facts of economic life organized around institutions or habits of thought in particular and "material civilization" and its life history in general (2011: 518). Thus mainstream economics narrows itself down to the pecuniary conception of economy and life as a whole, that is, the price theory. Price being both the means and order of the business as well as the pecuniary and popular conception of human life beyond economy, orthodox economic theory through the price theory and its foundational premises disregards and displaces the materialist views and ways of life, generating specific epistemological and ontological order of things as a conventional system of belief and institutional structure in a way to fit in with business life, ends, means and values.

Veblen sees the economy as a life process and is engaged in explicating the normative political rationality of the business order and its economics. In this sense, Veblen discloses the normative role of economic knowledge in the constitution and government of power relations and political rationalities. This is so, because, in his words: "The modern economic situation is a business situation, in that economic activity of all kinds is commonly controlled by business considerations" (2011: 521). Businessmen control the industrial system for their pecuniary/money/financial aims and gains to the detriment of the material welfare of the society at large. Classical, neoclassical and neoliberal economics, which is based on the 
reformulation of the classical political economy by marginalist neoclassical theory, have all certain performative role in the constitution of money/business order. The most recent assumptions, premises and promises of neoliberal economics are too directly associated with the 18th-century philosophical and legalistic system of right, equity, ownership, and liberty, which are all characterized in terms of the individualistic intercourses. Natural law had enriched individuals concerning rights but impoverished them regarding material welfare. In times of the neoliberal business order, the classical system of law of the 18th century, however, is under systematic reformulation by pecuniary ends and aggressive national politics of business enterprise against the industry and foreign countries. Among all, corporate ownership against individual property, impersonal (dis)relationship against faceto-face and personal relations under public culture and sphere, finance against reel economy, spiritualism and metaphysics against material sciences -by extension, immaterial wealth against material wealth-, competition against equity-based exchange- likewise, war against peace- flexibility of labour force under the forceful imposition of wages against dexterity and free bargaining, human capital against legal righteous and labourious human, homo economicus with self-interest constituting the economic order and political life against homo economicus to be sacrificed for saving the business order and politics (Brown, 2015: 201 222) are justified by the reformulations of the classical law made by the neoliberal business system of knowledge and order. Interestingly enough, the neoliberal business knowledge and order are more individualistic regarding moral values, culture, economic knowledge, and political rationality but its social order is becoming more based on the imbalanced monopolistic forces especially in economic and political life. Paradoxically, as noted, the neoliberal business order has to justify itself only on the grounds of the classical law of the 18th century, but at the same time, it has to reformulate it in the face of the changing conditions of the business order. One example of this is to conceive individuals as a corporation and vice versa in legalistic, cultural, political and economic terms. These anthropomorphic reformulations, from Veblen's point of view, are daily business affairs and maneuvers but also demonstrate the limits of the neoliberal business order.

Therefore, central to Veblen's critique of capitalism and economics is business. It is an all-encompassing term. Neoliberalism, which has been built on the modification of classical liberalism by neoclassical economics, its crisis and future can be best understood by working through the business order neoliberalism firmly established since the $1980 \mathrm{~s}$. The factors of the neoliberal business can be observed within a wide range of social, political, cultural and economic regulations. Accordingly, the condition and management of productive industry, technology and labour, the volume of production, material/economic welfare of the society (or equivalently 'the wealth of nations') and growth/depression/crises (that is, alternating economic periods or 'business' cycles), ways and modes of consumption, the structure and resources of property, incomes and earnings, economic model of enterprising, banking and finance, the capital and product markets (therefore, the price system), politics and the statecraft/government, capital -the physical stock of the means of production- and capitalization (the pecuniary use and valuation of physical capital for financial gains), liberal values, subjectivities and law, culture/cultural life and activities, and no less, sciences and system of social belief and knowledge are all shaped by business 
considerations. Veblen observes the condition of business order between the period of the late 19th century and 1929. That is, the conditions and consequences of the new industrial system, the World War I, Bolshevism and the Soviet Revolution, and the unstable 1920s in the capitalist world leading up to the Great Depression were framed in Veblen's theory of capitalism in relation to the then business order and global environment. He built the theory of business enterprise under the developing Fordist regime and pre-Keynesian structure and regulation of capitalism, but his theory applies to analyze the neoliberal order in the current post-Fordist era and its crisis.

First, the 2008 global financial, fiscal and industrial crisis can be described as the crisis of business. This means that financial, fiscal and industrial dimensions of the crisis are the outcomes of a certain capitalist aspiration. The meaning of this capitalist aspiration is presented clearly in Veblen's definition of business:

"Business is a pursuit of profits, and profits are to be had from
profitable sales, and profitable sales can be made only if prices are
maintained at a profitable level, and prices can be maintained only if
the volume of marketable output is kept within reasonable limits . . .
'Reasonable' means 'what the traffic will bear'; that is to say, 'what
will yield the largest net return"' (Veblen, 1964: 91).

Accordingly, in Veblen's perspective, the corporate owners control the industrial system for pecuniary ends and their most effective method is the 'sabotage' of the efficiency of the industrial system to maintain profitable prices in the market. The curtailment of the efficiency and volume of industrial output is the ordinary business method of 'sabotage' to evade the threat of 'overproduction' vis-à-vis the limited facility of the credit volume for the mass consumption. After the Fordist and Keynesian system of business order, neoliberal business ideology has developed a new system of sabotage not limited to the industrial system utilizing the fully developed and unregulated 'credit economy'. As the economic system has evolved from 'natural economy' through 'money economy' to, finally, a full 'credit economy', the business order has seized the opportunity to make profitable sales, which are not confined to vendible material consumption goods, through the expansion of consumption credits. As the structure of capital and the ownership changed into corporate, institutional forms in a way to free themselves from industrial employments for profitable sales under the credit economy, everything has turned into something as having moneyed capital value and the source of gains has become rested on the capitalization and recapitalization of the tangible wealth and productive materials to secure and enhance the presumptive earning-capacity (see 1958: ch. V-VI). In the neoliberal order of business, the source of gain rooting in the capitalization and recapitalization for the future income has extended to the domains beyond the industrial system in a way to cover the ordinary life of 'the common man'. The neoliberal business order reconstructs the 'common man' as a businessman who has self-responsibility for his welfare under the regime of corporation finance. Houses, cars, expenditures for education and the like have ceased to be material and cultural instruments for the establishment of the civilized human life and all become the means of putative earning-capacity based on presumptive future capitalized gains of the 
neoliberal business order thanks to new financial instruments (mortgages, derivatives, CDOs, CDSs, etc.) under the unregulated credit expansion (or 'pecuniary employments'). Corporate finance capital makes everything material or immaterial vendible and merchantable "through an interminable process of valuation and revaluation-i.e. a capitalization and recapitalization-on the basis of its presumptive earning-capacity" (1958: 76). In Veblen's estimation, the crisis of all capital in a fully developed business order bursts out when the discrepancy between putative and actual earning-capacity becomes discernible by the majority of people. This means that crisis is the end of the dream of 'free incomes' in the future which has built on the metaphysics and spiritual emotions of business management controlling the present and, no less, future of economic life, industry, and national/international politics.

That said, the 2008 crisis is generally conceived as the sovereign debt crisis in Europe, but as Mark Blyth (2013) correctly argues, it was a crisis of the private sector, which is the crisis of business economy and order. This means that a comprehensive understanding of the crisis and the post-crisis period requires the analysis of the neoliberal business order as a complex and multi-layered institutional order. This is important to identify who is responsible for it, wide-ranging causes and the effects of the crisis and re-imagining the future. Veblen provides a dissenting life politics for an alternative future which is free from the business order. For this, against the business constructivist metaphysics, spiritualism and emotionalism there should be a struggle in favor of the materialist and evolutionary point of view. It is because economics, as historian and social philosopher Michel Foucault (2007; 2008) shows, is the primary supplement of (neo)liberal art of government of life and politics that the departure point, as Veblen himself did, should be the reconstruction of economics in a materialist and evolutionary line in academic and popular areas of teaching economics in the form of social economics.

\section{Concluding Remarks}

Critics have frequently compared the 2008 crisis to the Great Depression of 1929. After 1929 Keynesianism reshaped the Fordist regime as the state policy, creating a new welfare system that took welfare outside the scope and strict control of business considerations and cycles by regulating the credit economy. Under the regulation of the international finance capital by the Bretton-Woods system and institutions, the conventional means of fiscal policy -taxation, public expenditures and the state debt- were used to enhance the productivity of industrial efficiency and establish a direct relation between wages and public finance system without recourse to the expansion of private credit economy. This has made the ways for a 'democratic capitalism' by constituting a social contract between the state, working classes, and capitalists. The last left the welfare system and the business order to the politics as the relatively autonomous power as long as the price system was maintained for profitable sales of the consumption goods. The early years of the 1970s witnessed the fiscal crisis of the Keynesian welfare state, and since the 1980s business has retaken the control of politics. Following Streeck's categorization and periodization, the 1980s was the period of the debt state as the dominant form of the 'business state' and from the early 1990s up to the 2008 crisis, the first period of consolidation in response to the crisis of the former 
developed. The 2008 crisis was quickly prevented to be developed into a deep business crisis thanks to the quantitative easing policies of global financial Keynesianism, but the crisis of post-war democratic system has been increasingly deepening and spreading during the second period of the consolidation state based on a new policy of social sacrifice, that is, austerity. With the 2008 crisis, the business order passed to another stage. In Veblen's terms, this is the constant sabotage of social life, economy, and democracy to the detriment of the material welfare of the society secured by the social rights and public administration. Social economics in times of the neoliberal business order and economics should rebuild itself vis$\grave{a}$-vis the challenges of the post-2008 neoliberal order. Fiscal sociology scholarship and the Veblenian social economics have the strong potential to renew the research agenda of critical heterodox economics and support social economics. Given that, in Veblen's words, " $[\mathrm{t}] \mathrm{he}$ indirect and incidental cultural bearing of business principles and business practice is wideranging and forceful" (Veblen, 1964: 181), from high politics to the micro domains of politics and the ordinary life, critical social economics as the material science of the public should be in the Kampflatz (battleground) of economic theories. To that end, fiscal sociology and the Veblenian institutional political economy will be at the service of the materialist and evolutionary social sciences for the sake of the material welfare of the community at large against the neoliberal business order and metaphysics.

\section{References}

Backhaus, J.G. (2004), “Joseph A. Schumpeter's Contributions in the Area of Fiscal Sociology: A First Approximation", Journal of Evolutionary Economics, 14, 143-151.

Blyth, B. (2013), Austerity: The History of a Dangerous Idea, Oxford: Oxford University Press.

Brown, W. (2015), Undoing the Demos: Neoliberalism's Stealth Revolution, New York: Zone Books.

Campbell, J.L. (1993), “The State and Fiscal Sociology”, Annual Review of Sociology, 19, 163-185.

Ebner, A. (2005), "Institutions, Entrepreneurship, and the Rationale of Government: An Outline of the Schumpeterian Theory of the State", in: J.G. Backhaus (ed.), Essays on Fiscal Sociology, Frankfurt a.M.: Peter Lang, 77-101.

Foucault, M. (2007), Security, Territory, Population: Lectures at the Collège de France 1977-1978, London: Palgrave Macmillan.

Foucault, M. (2008), The Birth of Biopolitics: Lectures at the Collège de France 1978-1979, London: Palgrave Macmillan.

Geiselberger, H. (ed.) (2017), The Great Regression, Malden/Cambridge: Polity Press.

Goldscheid, R. (1958 [1917/1925]), “A Sociological Approach to Problems of Public Finance”, in: R.A. Musgrave \& A.T. Peacock (eds.), Classics in the Theory of Public Finance, New York: St. Martin's Press, 202-213.

Koch, W. (1981), "Finanzsoziologie”, in G. Fischer (ed.), Handwörterbuch der Wirtschaftswissenschaft Band 3, Tübingen: J.C.B Mohr/Paul Siebeck, 97-106.

Lemke, T. (2011), Biopolitics: An Advanced Introduction, New York/London: New York University Press.

Martin, W.I. \& A.K. Mehrotra \& M. Prasad (eds.) (2009), The New Fiscal Sociology: Taxation in Comparative and Historical Perspective, Cambridge: Cambridge University Press. 
McCaffery, E. (2009), "Where's the Sex in Fiscal Sociology? Taxation and Gender in Comparative Perspective", in: W.I. Martin \& A.K. Mehrotra \& M. Prasad (eds.), The New Fiscal Sociology: Taxation in Comparative and Historical Perspective, Cambridge: Cambridge University Press, 216-236.

Musgrave, R. (1992), "Schumpeter's Crisis of the Tax State: An Essay in Fiscal Sociology”, Journal of Evolutionary Economics, 2, 89-113.

O'Connor, J. (1973), The Fiscal Crisis of the State, New York: St. Martin Press.

Schabas, M. (2005), The Natural Origins of Economics, Chicago/London: The University of Chicago Press.

Schumpeter, J. (1991 [1918]), "The Crisis of the Tax State", in: R. Swedberg (ed.), Joseph A. Schumpeter: The Economics and Sociology of Capitalism, Princeton: Princeton University Press, 99-140.

Schumpeter, J. (1950 [1942]), Capitalism, Socialism, and Democracy, New York: Harper \& Brothers Publishers.

Smelser, N.J \& R. Swedberg (eds.) (2005), The Handbook of Economic Sociology, Princeton/Oxford: Princeton University Press.

Streeck, W. (2014), Buying Time: The Delayed Crisis of Democratic Capitalism, London/New York: Verso.

Streeck, W. (2016), How will Capitalism End? Essays on a Failing System, London/New York: Verso.

Streeck, W. (2017), “A New Regime: The Consolidation State”, in: D. King \& P.L. Galès (eds.), Reconfiguring European States in Crisis, Oxford: Oxford University Press, 139-157.

Swedberg, R. (2003), Principles of Economic Sociology, Princeton/Oxford: Princeton University Press.

Veblen, T. (1958 [1904]), The Theory of Business Enterprise, New York: Mentor Books.

Veblen, T. (1994 [1921]), The Engineers and the Price System, London: Routledge/Thoemmes Press.

Veblen, T. (1964 [1919]), The Vested Interests and the Common Man ("The Modern Point of View and the New Order"), New York: Augustus M. Kelley.

Veblen, T. (1973 [1899]), The Theory of the Leisure Class, Boston: Houghton Mifflin Company.

Veblen, T. (1998 [1898]), "Why is Economics Not an Evolutionary Science?", Cambridge Journal of Economics, Special Issue on Veblenian Evolutionary Economics, 22(4), 403-414.

Veblen, T. (2011 [1909]), "The Limitations of Marginal Utility”, in C.C. \& G.M. Hodgson (eds.), Essential Writings of Thorstein Veblen, London/New York: Routledge, 513-524.

Wagner, R.E. (2007), Fiscal Sociology and the Theory of Public Finance: An Exploratory Essay, Cheltenham/Massachusetts: Edward Elgar. 